\title{
Comparison of computed tomography, endosonography, and intraoperative assessment in TN staging of gastric carcinoma
}

Departments of Internal Medicine K Ziegler

C Sanft

T Zimmer

M Zeitz

E O Riecken

Radiology

D Felsenberg

Pathology

H Stein

Surgery

C Germer

Medical Statistics, Klinikum Steglitz, Free University of Berlin C Deutschmann

Correspondence to: Dr K Ziegler, Klinikum Steglitz, FU Berlin, Department of Internal Medicine, Hindenburgdamm 30,1000 Berlin 45 , Germany. Accepted for publication 15 September 1992

\author{
K Ziegler, C Sanft, T Zimmer, M Zeitz, D Felsenberg, H Stein, C Germer, C Deutschmann, \\ E O Riecken
}

\begin{abstract}
From 1986 to 1990 a prospective comparative study was undertaken to compare the relative accuracy of computed tomography, endogastric ultrasonography, and intraoperative surgical assessment in evaluating the depth of invasion ( $T$ category) and involvement of lymph nodes ( $\mathbf{N}$ category) of patients with gastric carcinoma. One hundred and eight consecutive patients, who were treated by total gastrectomy and previously evaluated with computed tomography, endogastric ultrasonography, and intraoperative surgical assessment, entered the study. Results ( $T$ and $\mathbf{N}$ category) were compared with those of histopathological staging (pT and $\mathrm{pN}$ category). $\mathbf{T}$ categories were correctly staged in $43 \%$ of cases with computed tomography, $86 \%$ with endogastric ultrasonography, and $56 \%$ with intraoperative surgical assessment. Computed tomography scanning correctly staged $51 \%$ of all $\mathrm{N} 1$ and $\mathrm{N} 2$ lymph nodes compared with $\mathbf{7 4 \%}$ for endogastric ultrasonography and $\mathbf{5 4 \%}$ for intraoperative surgical assessment. In general, computed tomography was more accurate for advanced stages of cancer and showed a tendency to overstage the $T$ category and understage $\mathbf{N}$ category of gastric tumours. By contrast, endogastric ultrasonography was equally accurate for all $T$ categories and showed an understaging for $\mathbf{N}$ categories. Intraoperative surgical assessment overstaged early $T$ stages, understaged $T 4$ tumours, and was equally accurate for all grades of $\mathbf{N}$ categories. Computed tomography scanning and intraoperative surgical assessment of $\mathbf{T}$ and $\mathbf{N}$ categories were of little value in staging of gastric carcinoma. Endogastric ultrasonography is more accurate than computed tomography scanning and intraoperative surgical assessment. Therefore endogastric ultrasonography should be introduced in the preoperative assessment of patients with gastric carcinoma.

(Gut 1993; 34: 604-610)
\end{abstract}

Despite the decreasing incidence of gastric adenocarcinoma, this dismal disease remains one of the most common malignant human tumours. ${ }^{1-3}$ The five year survival rate of all patients with gastric cancer is $6-25 \%$ and depends on tumour stage ${ }^{+}$and histological type. ${ }^{5}$ In roughly $60 \%$ of the patients an operation with curative intent is possible. ${ }^{6-8}$ About $15-30 \%$ undergo only explorative laparotomy because the tumour is found to be unresectable. ${ }^{9}$ An accurate preeoperative classification of the most significant prognostic factors of gastric cancer, such as depth of invasion ( $\mathrm{T}$ category) and involvement of lymph nodes ( $N$ category), would allow better planning of appropriate treatment. The goal is to prevent under or overtreatment with their inherent inadequate morbidity and mortality. ${ }^{10}$

In the past, staging of gastric tumours was based on extracorporal ultrasonic and radiological contrast studies. These proved to be insufficient for the accurate determination of operability $^{11} 12$ and therefore have little influence on the decision about adequate treatment today..$^{13}$

Computed tomography has been employed in recent years to detect unresectable gastrointestinal tumours. ${ }^{13-29}$ Among five prospective studies $^{2122} 242529$ there are only two applying histological (pTNM) staging as the gold standards. ${ }^{24}$ The opinions as to the value of computed tomography scanning in preoperative assessment range between enthusiasm ${ }^{13-17} 20222529$ and disappointment. ${ }^{18-21} 2+26-28$

Data on the accuracy of intraoperative surgical assessment are rare. A prospective multicentre study that compared intraoperative surgical assessment with pathological staging showed a correct assessment in only one third of the cases. ${ }^{30}$ The endoscopically guided intraluminal application of ultrasound (endosonography) provides a new modality for staging gastrointestinal tumours with high accuracy. ${ }^{31-33}$ However, no studies to date have compared endogastric ultrasonography with computed tomography, intraoperative staging, and histological assessment of gastric carcinoma.

This study compares computed tomography, endogastric ultrasonography, and intraoperative surgical assessment with histopathological staging for $\mathrm{T}$ and $\mathrm{N}$ categories of gastric adenocarcinoma in 108 patients who underwent a gastrectomy.

Patients and methods

PATIENTS

From February 1986 to September 1990 all inpatients with gastric carcinoma in the medical and surgical units of the University Hospital, Klinikum Steglitz, Free University of Berlin, who were subjected to tumour resection, were entered into the study. A total of 108 patients were investigated (median age: 58 , range: $29-82$ years, 50 women, 58 men).

One hundred and one patients had histologic- 


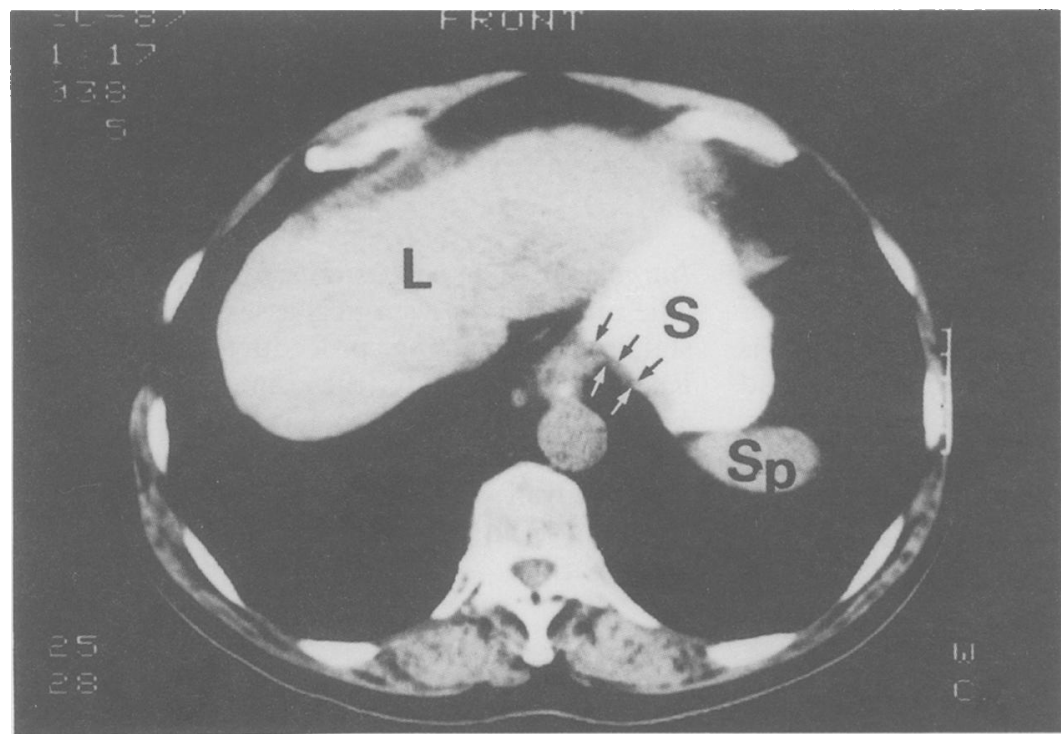

Figure 1: Computed tomography scan of an early gastric carcinoma. The tumour is located in the subcardial region and is characterised by a slight thickening of the gastric wall (arrows). $L$, liver; $S$, stomach; $S p$, spleen.

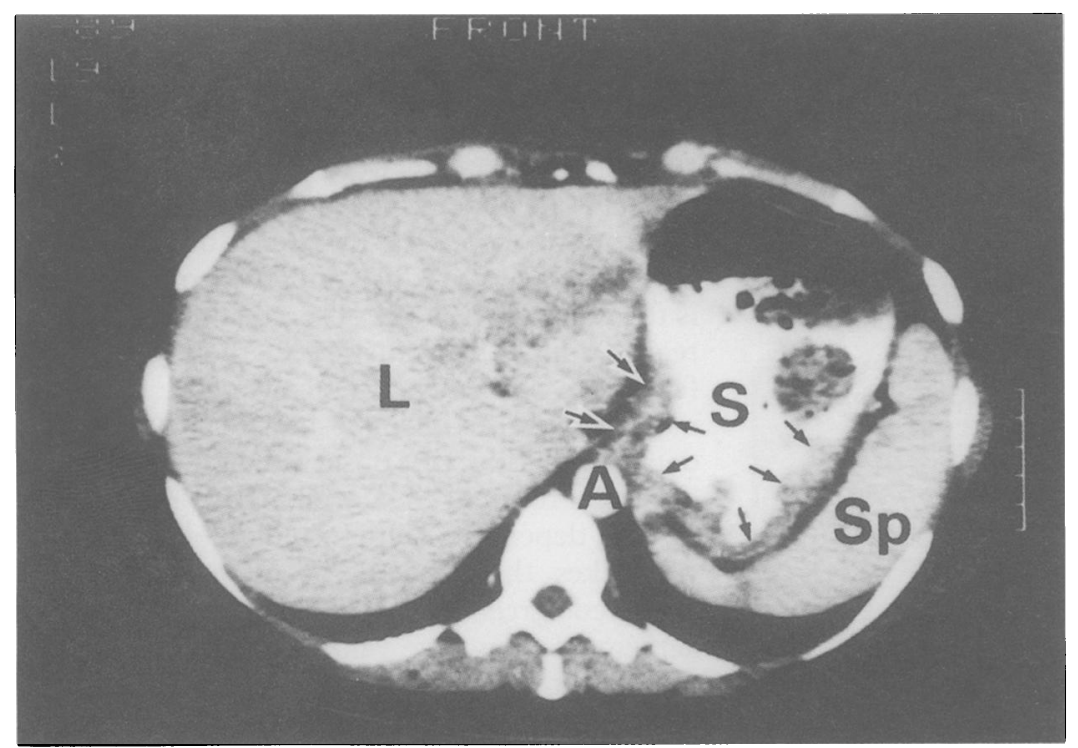

Figure 2: Thickness of the gastric wall of more than $12 \mathrm{~mm}$ (arrows) shown by computed tomography, indicating an advanced gastric tumour (T2/T3 category). The fat layer is still visible. A, aorta; other abbreviations as for Fig 1.

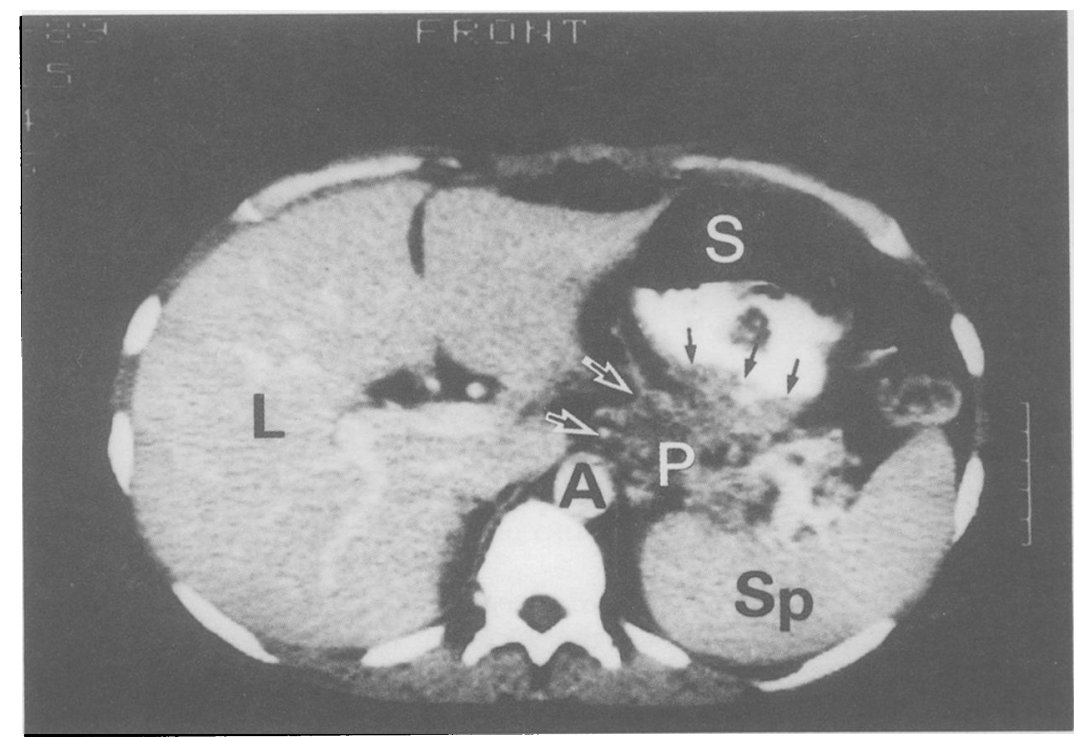

Figure 3: Computed tomography scan of a gastric carcinoma with infiltration of the pancreas (T4 category). P, pancreas; other abbreviations as for Figs 1 and 2. ally verified adenocarcinoma of the stomach, of whom 62 had adenocarcinomas of the intestinal type and 39 of the diffuse type. ${ }^{5}$ Seven patients showed a signet ring carcinoma. Thirty seven of these tumours were located in the fundus, 43 in the corpus, and 28 in the antrum of the stomach.

\section{METHODS}

\section{Computed tomography}

Computed tomography was carried out no more than 14 days before operation with a Somatom DRG or DRH (Siemens Co, Germany), section width $2 \mathrm{~mm}$, scanning time 4.8 seconds. All patients were given $150-250 \mathrm{ml}$ Ultraquist 300 (Schering AG Berlin, Germany) contrast medium intravenously and $100-200 \mathrm{ml} 1-2 \%$ Gastrografin (Schering AG Berlin, Germany) orally immediately before scanning. In addition, $20 \mathrm{mg}$ of hyoscine bromide was given intravenously to reduce peristalsis. Horizontal sections at $2 \mathrm{~mm}$ intervals were obtained from above the diaphragm to the level of aortic bifurcation.

In computed tomography the criteria for the depth of tumour infiltration were: $\mathrm{T} 1$, intraluminal mass and/or localised slight thickening of the gastric wall ( $>8 \mathrm{~mm} \leqslant 12 \mathrm{~mm}$ ) (Fig 1). $\mathrm{T} 2 / \mathrm{T} 3$, thickening of the gastric wall $(>12 \mathrm{~mm})$ but no evidence of direct tumour extension into adjacent organs (distinguishable fat layer) (Fig 2). T2/T3 stages were combined because computed tomography could not differentiate between $\mathrm{T} 2$ and $\mathrm{T} 3$ categories of infiltration. T4, thickening of the gastric wall with evidence of tumour extension into adjacent organs (lack of a fat layer between gastric mass and adjacent organ) (Fig 3).

Lymph node metastases were determined by computed tomography as enlarged lymph nodes of more than $8 \mathrm{~mm}$ in diameter. ${ }^{22}$

\section{Endogastric ultrasonography}

Endogastric ultrasonography was performed by means of a mechanical sector scan Olympus EU-M3 (Olympus Optical Co, Germany) with a $360^{\circ}$ view and a rated frequency of selective $7 \cdot 5$ or $12 \mathrm{MHz}$.

The patients were examined in a left lateral position after premedication with diazepam given intravenously. The ultrasonic endoscope was introduced and advanced into the stomach. For optimal transmission of ultrasound, the stomach was filled with 300 to $500 \mathrm{ml} 0.9 \% \mathrm{NaCl}$ through the rinsing channel of the endoscope during examination, which usually lasted 10 to 15 minutes. The ultrasonic aspect of tumours and their contiguous structures were assessed by moving the tip of the endoscope along all parts of the stomach. The findings were recorded with a polaroid camera.

In endosonography, tumours were identified by thickening and disruption of the typical five layered configuration of the parietal wall by a hypoechoic mass. ${ }^{33}$ Dependent on the depth of tumour infiltration into these layers the $T$ category was assessed as: T1, tumour has disturbed echogenic layers 1 through 3 (Fig 4). T2, tumour has disturbed echogenic layers 1 through 
Figure 4: Endosonographic appearance of an early gastric cancer ( $T 1$ category). Note the untouched layer of the muscularis propria (arrows). T, tumour; other abbreviations as for Fig 1 .

Figure 5: Gastric tumour (T) with inflitration of the muscularis propria. The tumour is

endosonographically sharply delineated indicating lack of infiltration of adjacent fatty tissue (T2 category). Abbreviations as for Figs 1 , 3 , and 4 .
4 (Fig 5). T3, tumour has disturbed echogenic layers 1 through 5 with irregular finger like growth into perigastric fatty tissue (Fig 6). T4, tumour has disturbed all echogenic layers with clear infiltration of contiguous organs (Fig 7).

A differentiation of $\mathrm{T} 2$ and $\mathrm{T} 3$ categories is not possible in certain regions of the stomach such as the ligamentum gastrocolicum, ligamentum gastrohepaticum, and the omentum major or minor, because in these minor regions there is fatty tissue between muscularis propria and serosa. Therefore tumour infiltration into fatty tissue mimics a T3 category instead of a possible T2 category.
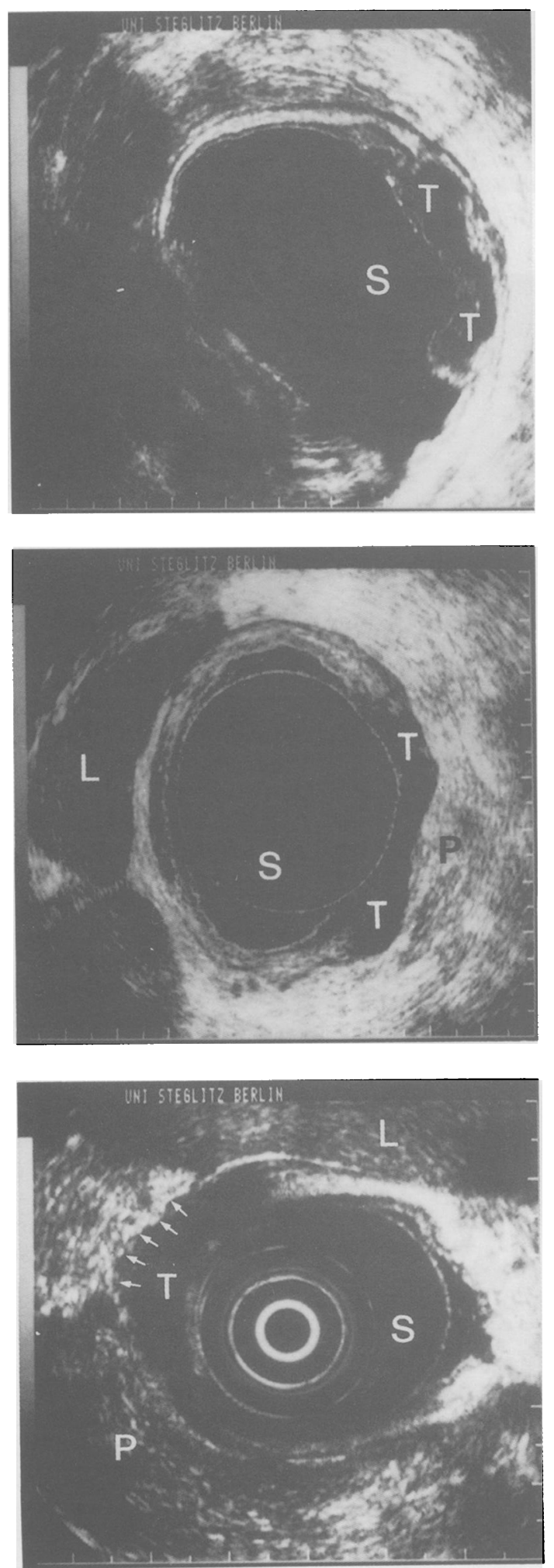

The involvement of regional lymph nodes ( $\mathrm{N}$ category) was shown by visualisation of perigastric lymph nodes. Lymph nodes of all sizes with a sharp margin and a hypoechoic echographic pattern were considered to be infiltrated.

Intraoperative surgical assessment

The intraoperative surgical assessment used the standardised staging procedure described by Rhode et al..$^{36}$ Briefly, the primary tumour was assessed with respect to location, size, multiplicity, degree of penetration through the stomach wall, and invasion of contiguous structures. Also, involvement of nodes was assessed by palpation.

\section{Postoperative histopathological assessment}

Resected tumours were assessed histopathologically according to the TNM classification of the International Union of Cancer Classification $1987 .{ }^{3+35} 37$

\section{Statistical analysis}

The findings from computed tomography, endogastric ultrasonography, and intraoperative surgical assessment were compared with the results of postoperative histopathological assessment. The simplest measure for agreement between one procedure and the gold standard is the ratio between the observed finding and the real finding. This statistical method ignores the fact of an agreement by chance. We therefore used the weighted Kappa statistic $(\mathrm{Kw})^{38}$ for our data comparing the observed agreement with chance agreement. The weighted Kappa ranges up to 1 , depending on the strength of agreement $\mathrm{Kw}$ takes the value zero (no agreement), if observed agreement is equal to expected chance agreement. Negative values of $\mathrm{Kw}$ indicate disagreement and positive values agreement. We tested the hypothesis $\mathrm{Kw}=0$ and assessed the value of $\mathrm{Kw}$ for strength of agreement with the guidelines of Landis and Koch. ${ }^{34}$

The validities of computed tomography, endogastric ultrasonography, and intraoperative surgical assessment staging with respect to the familiar indices of sensitivity, specificity, and positive and negative predictive values were estimated. ${ }^{+0+2}$ We finally used a modified McNemar X2-test ${ }^{3 \mathrm{~B}}$ to prove whether a method systematically under or overstaged the $\mathrm{T}$ and $\mathrm{N}$ categories against the gold standard.

The study design was approved by the local ethics committee.

\section{Results}

STAGING ACCURACY OF TUMOUR INFILTRATION (T CATEGORY)

\section{Computed tomography}

When the accuracy of computed tomography was compared with histopathological assessment, early gastric cancers $(T 1, n=22)$ were staged correctly by computed tomography as T1 category in four cases, whereas six had a normal border is poorly defined due to infiltration of fatty tissue (arrows). Abbrevia
for Figs 1 and 3. 


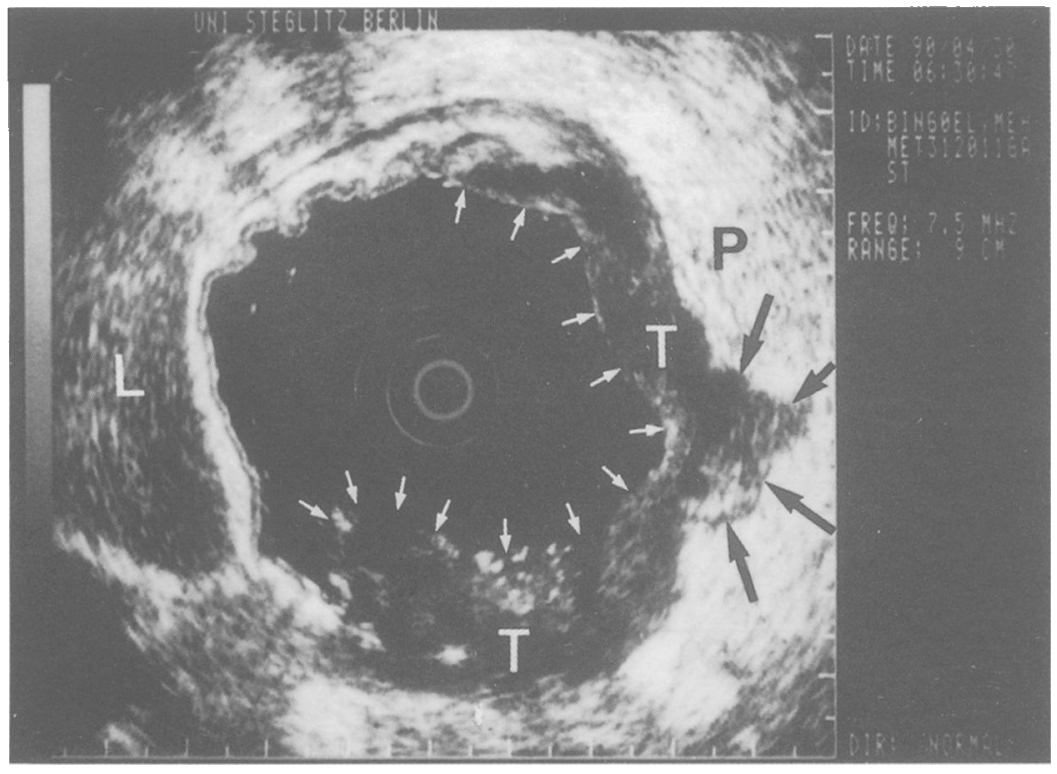

Figure 7: Endosonographic aspect of an advanced gastric tumour with infiltration of the pancreas (black arrows). Abbreviations as for Figs 1 , 3 , and 4 .

CT scan (T0 category) and 12 were overstaged as $\mathrm{T} 2 / 3$ tumours. Tumours with $\mathrm{T} 2$ or $\mathrm{T} 3$ category were staged correctly in 34 out of 68 cases with 14 patients understaged and 20 patients overstaged; of 18 tumours with a T4 category eight tumours were staged correctly. In all groups the sensitivity was not higher than $0 \cdot 5$. Only the specifities for stage T1 and T4 achieved statistical significance. The Kappa coefficient showed the

TABLE I Accuracy of computed tomography staging of 108 resected gastric tumours

\begin{tabular}{|c|c|c|c|c|c|c|c|c|}
\hline \multirow{2}{*}{$\begin{array}{l}\text { Stage by } \\
\text { computed } \\
\text { tomography }\end{array}$} & \multicolumn{8}{|c|}{ Stage by pathological assessment } \\
\hline & TO & $T I$ & $T 2$ & T3 & $T 4$ & NO & $N 1$ & $N 2$ \\
\hline \multirow{7}{*}{$\begin{array}{l}\text { T0 } \\
\text { T1 } \\
\text { T2/3 } \\
\text { T4 } \\
\text { N0 } \\
\text { N1 } \\
\text { N2 }\end{array}$} & & 6 & 2 & & & \multirow{3}{*}{\multicolumn{3}{|c|}{$\begin{array}{l}\text { Computed tomography } \\
\text { understaging }\end{array}$}} \\
\hline & & $4^{\star}$ & 8 & 4 & & & & \\
\hline & & 12 & $10^{\star}$ & $24^{\star}$ & 10 & & & \\
\hline & & & 12 & 8 & $8^{\star}$ & & & \\
\hline & \multirow{3}{*}{\multicolumn{5}{|c|}{ Computed tomography overstaging }} & $29^{\star}$ & 20 & 12 \\
\hline & & & & & & 21 & $24^{\star}$ & \\
\hline & & & & & & & & $2^{\star}$ \\
\hline
\end{tabular}

*Correct staging. Figures are numbers of patients.

TABLE II Accuracy of endogastric ultrasonography staging of 108 resected gastric tumours

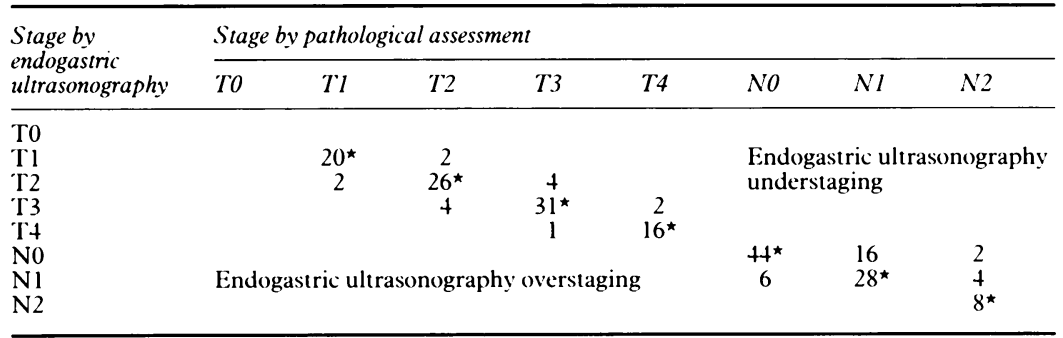

*Correct staging. Figures are numbers of patients.

TABLE III Accuracy of intraoperative surgical assessment staging of 108 resected gastric tumours

\begin{tabular}{|c|c|c|c|c|c|c|c|c|}
\hline \multirow{2}{*}{$\begin{array}{l}\text { Stage by } \\
\text { intraoperative } \\
\text { surgical assessment }\end{array}$} & \multicolumn{8}{|c|}{ Stage by pathological assessment } \\
\hline & TO & $T l$ & $T 2$ & $T 3$ & $T 4$ & NO & Nl & $N 2$ \\
\hline Г० & & 2 & 2 & \multirow{5}{*}{$\begin{array}{c}32^{\star} \\
4\end{array}$} & \multirow{5}{*}{$\stackrel{14}{4^{\star}}$} & \multirow{3}{*}{\multicolumn{3}{|c|}{$\begin{array}{l}\text { Intraoperative surgical } \\
\text { assessment understaging }\end{array}$}} \\
\hline T1 & & $14^{\star}$ & 4 & & & & & \\
\hline $\mathrm{T} 2$ & & 6 & $10^{\star}$ & & & & & \\
\hline T3 & & & 16 & & & & & \\
\hline $\mathrm{T} 4$ & & & & & & & & \\
\hline N0 & \multirow{3}{*}{\multicolumn{5}{|c|}{ Intraoperative surgical assessment overstaging }} & $26^{\star}$ & 17 & 8 \\
\hline N1 & & & & & & 20 & $26^{\star}$ & \\
\hline $\mathrm{N} 2$ & & & & & & 4 & 1 & $6^{\star}$ \\
\hline
\end{tabular}

*Correct staging. Figures are numbers of patients same result, which is only a fair agreement with the gold standard. There was no significant over or understaging (Tables I and IV).

\section{Endogastric ultrasonography}

Evaluation of the tumour stage was possible in all cases. Carcinomas of the stomach restricted to the mucosa and submucosa $(T 1, n=22)$ were staged correctly by endosonography as stage $\mathrm{T} 1$ in 20 cases. Twenty six of 32 T2 tumours were correctly staged, whereas four were overstaged as stage T3 and two were understaged as T1. A differentiation between $\mathrm{T} 3$ and $\mathrm{T} 4$ categories of gastric tumours $(n=54)$ could be made endosonographically in all but seven cases with understaging in six cases and overstaging in one case (Table II). As Table IV shows, the T staging by endogastric ultrasonography was fairly correct compared with the gold standard. The difference between the number of cases who were over or understaged was also non-significant.

\section{Intraoperative surgical assessment}

In assessment of tumour stage, surgeons could not palpate two $\mathrm{T} 1$ tumours and overstaged six of these as T2 tumours. Twenty two out of 32 tumours of $\mathrm{T} 2$ category were staged incorrectly with six of these understaged and 16 overstaged as T3 tumours. Four of 36 T3 tumours were overstaged and 14 of 18 T4 tumours were understaged (Table III). Sensitivity and specificity varied to a great extent for the separate stages. Sensitivity was high enough only for stage $\mathrm{T} 3$, whereas specificity produced sufficient values for stages $T 1, T 2$, and $T 4$. For the predictive values, intraoperative surgical assessment produced acceptable results only for stage T1. Altogether intraoperative surgical assessment showed a moderate agreement with the gold standard and no significant over and understaging (Table IV).

STAGING ACCURACY OF LYMPH NODE INVOLVEMENT (N1 AND N2 CATEGORY)

\section{Computed tomography}

Of 44 patients with histologically verified infiltrated lymph nodes 20 cases were understaged by computed tomography as N0 category. With respect to the $\mathrm{N} 2$ category, 12 patients of 14 were understaged as N0 category. Computed tomography correctly predicted regional lymph node metastases (N1 and N2 category) in 26 of 58 cases (Table 1). No evidence of lymph node involvement was found in 29 of 50 tumours without histological lymph node metastasis. By statistical analysis computed tomography showed a slight agreement $(\mathrm{Kw}=0.071)$ compared with histopathology (Table V).

\section{Endogastric ultrasonography}

Fifty eight patients had histopathologically verified lymph node metastases, of whom 36 were correctly detected by endosonography (Table II). In the remaining 22 cases 18 were found to be false negative and four as $\mathrm{N} 1$ instead of $\mathrm{N} 2$ 
TABLE IV Sensitivity, specificity, and predictive values of computed tomography, endogastric ultrasonography, and intraoperative surgical assessment with respect to T categories

\begin{tabular}{|c|c|c|c|c|c|c|}
\hline \multirow[b]{2}{*}{ Method } & \multirow[b]{2}{*}{ Categories } & \multirow[b]{2}{*}{ Sensitivity } & \multirow[b]{2}{*}{ Specifity } & \multicolumn{2}{|c|}{ Predictive value } & \multirow[b]{2}{*}{$K w^{\star}$} \\
\hline & & & & Positive & Negative & \\
\hline Computed tomography & $\begin{array}{l}\text { T1 } \\
\text { T2/3 } \\
\text { T4 }\end{array}$ & $\begin{array}{l}0 \cdot 18 \\
0 \cdot 50 \\
0 \cdot 44\end{array}$ & $\begin{array}{l}0.86 \\
0.45 \\
0.78\end{array}$ & $\begin{array}{l}0.25 \\
0.61 \\
0.29\end{array}$ & $\begin{array}{l}0.80 \\
0.35 \\
0.88\end{array}$ & $0 \cdot 209$ \\
\hline Endogastric ultrasonography & $\begin{array}{l}\text { T1 } \\
\text { T2 } \\
\text { T3 } \\
\text { T4 }\end{array}$ & $\begin{array}{l}0.91 \\
0.81 \\
0.86 \\
0.89\end{array}$ & $\begin{array}{l}0.98 \\
0.92 \\
0.92 \\
0.99\end{array}$ & $\begin{array}{l}0.91 \\
0.81 \\
0.84 \\
0.94\end{array}$ & $\begin{array}{l}0.98 \\
0.92 \\
0.93 \\
0.98\end{array}$ & $0 \cdot 873$ \\
\hline Intraoperative surgical assessment & $\begin{array}{l}\text { T1 } \\
\text { T2 } \\
\text { T3 } \\
\text { T4 }\end{array}$ & $\begin{array}{l}0.64 \\
0.31 \\
0.89 \\
0.22\end{array}$ & $\begin{array}{l}0.95 \\
0.92 \\
0.58 \\
0.96\end{array}$ & $\begin{array}{l}0.78 \\
0.63 \\
0.51 \\
0.50\end{array}$ & $\begin{array}{l}0.91 \\
0.76 \\
0.91 \\
0.86\end{array}$ & 0.570 \\
\hline
\end{tabular}

* Weighted Kappa

TABLE V Sensitivity, specificity, and predictive values of computed tomography, endogastric ultrasonography, and intraoperative surgical assessment with respect to $N$ categories

\begin{tabular}{|c|c|c|c|c|c|c|}
\hline \multirow[b]{2}{*}{ Method } & \multirow[b]{2}{*}{ Categories } & \multirow[b]{2}{*}{ Sensitivity } & \multirow[b]{2}{*}{ Specifity } & \multicolumn{2}{|c|}{ Predictive value } & \multirow[b]{2}{*}{$K w^{\star}$} \\
\hline & & & & Positive & Negative & \\
\hline Computed tomography & $\begin{array}{l}\text { N0 } \\
\text { N1 } \\
\text { N2 }\end{array}$ & $\begin{array}{l}0.58 \\
0.55 \\
0.14\end{array}$ & $\begin{array}{l}0.45 \\
0.67 \\
1.00\end{array}$ & $\begin{array}{l}0.48 \\
0.53 \\
1.00\end{array}$ & $\begin{array}{l}0.55 \\
0.68 \\
0.89\end{array}$ & 0.071 \\
\hline Endogastric ultrasonography & $\begin{array}{l}\text { N0 } \\
\text { N1 } \\
\text { N2 }\end{array}$ & $\begin{array}{l}0.88 \\
0.64 \\
0.57\end{array}$ & $\begin{array}{l}0.69 \\
0.84 \\
1.00\end{array}$ & $\begin{array}{l}0.71 \\
0.74 \\
1.00\end{array}$ & $\begin{array}{l}0.87 \\
0.77 \\
0.94\end{array}$ & 0.597 \\
\hline Intraoperative surgical assessment & $\begin{array}{l}\text { N0 } \\
\text { N1 } \\
\text { N2 }\end{array}$ & $\begin{array}{l}0.52 \\
0.59 \\
0.54\end{array}$ & $\begin{array}{l}0.57 \\
0.69 \\
0.92\end{array}$ & $\begin{array}{l}0.50 \\
0.56 \\
0.43\end{array}$ & $\begin{array}{l}0.58 \\
0.71 \\
0.95\end{array}$ & $0 \cdot 183$ \\
\hline
\end{tabular}

* Weighted Kappa

TABLE VI Staging of gastric carcinoma by computed tomography (results of comparative studies with the TNM classification)

\begin{tabular}{|c|c|c|c|c|}
\hline Author & Study design & Standard & Criteria of staging & Correct staging \\
\hline $\begin{array}{l}\text { Ruf } e t a l^{2+} \\
\text { Schröder } e t a l^{26} \\
\text { Mason } e t a l^{24} \\
\text { Sussmann } e t a l^{14} \\
\text { Stöltzing } \text { et } \text { al }^{21}\end{array}$ & $\begin{array}{l}\text { Prospective } \\
\text { Retrospective } \\
\text { Prospective } \\
\text { Retrospective } \\
\text { Prospective }\end{array}$ & $\begin{array}{l}\text { Histology } \\
\text { Operation + histology } \\
\text { Operation } \\
\text { Operation + histology } \\
\text { Histology }\end{array}$ & $\begin{array}{l}\text { pTNM } \\
\text { TNM } \\
\text { TNM } \\
\text { TNM } \\
\text { pTNM }\end{array}$ & $\begin{array}{l}\mathrm{T}=56 \%, \mathrm{~N}=55 \% \\
\mathrm{~T}=\mathbf{9 0} \%, \mathrm{~N}=50 \% \\
\mathrm{~T}+\mathrm{N}=48 \% \\
\mathrm{~T}+\mathrm{N}+\mathrm{M}=53 \% \\
\mathrm{~T}=45 \%, \mathrm{~N}=42 \%\end{array}$ \\
\hline
\end{tabular}

category. The absence of lymph node metastases was classified correctly in 44 out of 50 cases. In the remaining six cases, the findings were false positive predicting an $\mathrm{N} 1$ category of lymph node involvement. The strength of agreement with the gold standard was moderate (Table V).

\section{Intraoperative surgical assessment}

Among 58 patients with infiltrated lymph nodes, 25 patients were understaged and one patient was overstaged (Table III). Of 50 patients without lymph node involvement, 26 patients were staged correctly. For the $\mathrm{N}$ categories, sensitivities of all staging methods tested had only a moderate strength of agreement except computed tomography with a very low value for N2 stage and endogastric ultrasonography with a value greater than 0.8 for N0 stage. The predictive values in all stages were greater than 0.7 only for endogastric ultrasonography (Table V).

\section{Discussion}

Our study shows that of the techniques tested, endosonography is the most reliable procedure for preoperative staging of gastric carcinoma. With endosonography it was possible to assess correctly the depth of tumour infiltration ( $T$ stage) in $86 \%$ (Table II) with the highest predictive values (Table IV), while computed tomography only allowed a correct classification in
$43 \%$ (Table I). Intraoperative assessment allowed prediction of tumour stage in only $56 \%$ of the cases (Table III). Endosonography also showed metastatic involvement of regional lymph nodes ( $\mathrm{N}$ stage) with higher predictive values than computed tomography and intraoperative surgical assessment (Table V).

The prognosis of gastric carcinoma mainly depends on the tumour stage. The five year survival rate after gastrectomy is $85 \%-90 \%$ at stage I (T1, N0, M0), $45 \%-55 \%$ in stage II (T2-3, N0, M0), 5\%-20\% in stage III (T1-3, $\mathrm{N} 1-3, \mathrm{M} 0)$, and $3 \%$ in stage IV (T1-4, N1-3, Ml). ${ }^{+3}$ Selection of surgical treatment procedures for gastric carcinoma depends on preoperative tumour staging, because morbidity and survival differ significantly depending on resection for cure, resection for palliation, bypass procedures, or laparotomy alone. Therefore accurate pre intraoperative assessment concerning the TNM stage is of major importance to avoid operative procedures inappropriate for the stage of the tumour. Abdominal computed tomography has been widely used in staging tumours of the stomach. The size and location of a gastric mass can be documented as areas of gastric wall thickening, with the normal thickness in a distended stomach defined as less than $8 \mathrm{~mm}$. Furthermore, a lack of the fat layer between the gastric mass and an adjacent organ indicates direct invasion. On the other hand, computed tomography cannot differentiate 
between single layers of the intestinal wall. ${ }^{+}$ This limits the use of computed tomography in separating early (T1) from advanced tumour stages (T2/T3).

Early computed tomography studies were focused primarily on visualisation and development of diagnostic criteria for gastric masses. ${ }^{1+15}$ Moss et al were the first to develop computed tomography criteria for staging gastric carcinoma ${ }^{16}$ and found the procedure to be useful in predicting resectability. Further retrospective $^{1718202728}$ and prospective ${ }^{2225}$ studies were done to clarify the sensitivity of computed tomography scans with respect to infiltration of adjacent organs. All these studies used as a gold standard the intraoperative assessment of tumour stage without consideration of the histopathological TNM classification. Since then the accuracy of intraoperative surgical assessment has been called into question, as shown by Thon and Rhode ${ }^{456}$ and in this study. Therefore studies with intraoperative surgical assessment as gold standard are of questionable reliability. Ruf and co-workers performed the first prospective comparative study with the pTNM state as gold standard. ${ }^{24}$ They found that computed tomography correctly predicts the $\mathrm{T}$ category in $56 \%$ and the $\mathrm{N}$ category in $55 \%$ of the cases.

One other study investigated the validity of computed tomography both under study conditions and routine clinical conditions. ${ }^{21}$ For the $\mathrm{T}$ categories a validity of $45 \%$ was found in the study group $v 43 \%$ in the routine clinical group, and for the $\mathrm{N}$ categories a validity of $42 \% v 55 \%$ (Table VI). The results of both studies are comparable with our findings.

The intraoperative estimations of tumour infiltration and lymph node metastases usually serve as major points for the decision about which operation should be performed in a patient with gastric carcinoma. The intraoperative surgical staging fails to diagnose the exact tumour stage, however, in about $50 \%$ of the cases. ${ }^{43}$ These prospective studies have shown that the $T$ stage was underestimated whereas the $\mathrm{N}$ stage was overestimated. Therefore, as confirmed in our study, intraoperative staging alone does not allow the selection of the best surgical procedure for an individual patient.

Surgical procedures based on intraoperative histology of standardised frozen sections of lymph nodes and resection lines may improve determination of both $\mathrm{T}$ and $\mathrm{N}$ categories. ${ }^{+6}$ Also, intraoperative surgical assessment may be supplemented by intraoperative ultrasonic examination for most distant metastasis - for example, in the liver.

The clinical usefulness of endosonography shown in our study is based on the higher resolution leading to differentiation of various histological structures of the intestinal wall. Endogastric ultrasonography may penetrate with a good resolution about $6-8 \mathrm{~cm}$ into the tumour and the adjacent organs. Also, artefacts due to body movement do not disturb endogastric ultrasonography as they do in computed tomography. In accordance with our results Tio et al found an overall accuracy for endogastric ultrasonography of $83 \%$ for the $T$ category and $66 \%$ for the $\mathrm{N}$ category in 80 patients with gastric carcinomas, when endogastric ultrasonography was compared with histological assessment of resected specimens. ${ }^{31}$ In advanced stages gastric tumours may become stenotic and prevent entry of the endosonoscope. In these cases endosonography can only visualise the proximal part of these tumours. Therefore endosonographical staging may be limited. In our study only two patients had tumour stenoses that could not be passed by the instrument. Despite this fact the tumour stages were defined correctly as T3 N1 and as $\mathrm{T} 4 \mathrm{~N} 1$.

Similar results were obtained recently from our group with endogastric ultrasonography in preoperative staging of oesophageal carcinoma. ${ }^{47}$

There are certain regions of the stomach where it is difficult to distinguish the muscular layer from the serosal layer by endosonography. In these areas the serosa is separated from the muscularis by fatty tissue as mentioned under methods. As a result T2 categories may be overstaged as T3 categories. This is not of clinical relevance, however, as the surgical treatment is the same for T2 and T3 carcinomas.

In summary, our study has shown that endogastric ultrasonography is superior to computed tomography and intraoperative surgical assessment in staging $\mathrm{T}$ and $\mathrm{N}$ categories of malignant gastric tumours. Computed tomography is of little value for preoperative decision making. As endogastric ultrasonography has by far the highest sensitivity and specificity for correct TN classification, the introduction of this technique in the preoperative diagnostic programme allows much better selection of inoperable patients. This method may therefore avoid unnecessary and potentially risky operations.

Supported in part by a grant from the Maria Sonnenfeld-Stiftung. Part of this work was presented at the Annual Meeting of the American Gastroenterological Association 1988, New Orleans. (Abstract: Gastroenterology 1989; 95: (suppl): A111.)

1 Sipponen P, Järvi O, Kekki M, Siurala M. Decreased incidence of intestinal and diffuse types of gastric carcinoma in Finland during a 20 year period. Scand $\mathcal{F}$ Gastroenterol 1987; 22: 865-71

2 Segi M, Kuihara N. Cancer mortality for selected sites in 24 countries. No 4 (1962-63). Sendai, Japan: Japan Cancer Society, Department of Public Health, Tohoka University, School of Medicine, 1966.

3 Silverberg E. Cancer statistics 1980. A Cancer fournal for Clinicians 1980; 30: 23-38.

4 Maruyama K. The most important prognostic factors for gastric cancer patients. A study using univariate and multivariate analyses. Scand $\mathcal{F}$ Gastroenterol 1987; 22 (suppl 133): variate.

5 Lauren P. The two histologic main types of gastric carcinoma: diffuse and so-called intestinal-type carcinoma. Acta Pathological Microbiological Scandinavica 1965; 64: 31-49.

6 Scott HW, Adkins RB, Sawyers JL. Results of an aggressive surgical approach to gastric carcinoma during a twentythree-year period. Surgery 1985; 97: 55-9.

7 Günther B. Magencarcinoma. Spätprognose nach radikalen Eingriffen. Langenbecks Arch Chir 1987; 372: 593-7.

8 Inberg MV, Heinonen R, Rantakokko V. Surgical treatment of gastric carcinoma. A regional study of 2,590 patients over a 27 year period. Arch Surg 1975; 110: 703-7.

9 Lundh HG, Burn JI, Kolig G, Richard CA, Thomson JWW, van Elk PJ, Oszacki J. A co-operative international study of gastric cancer. Ann R Coll Surg Engl 1974; 54: 219-28.

10 Rhode H, Rau E, Gebbensleben B, Stützer H, Köster R Salzberger B, Ahrens P. What causes in-hospital mortality of surgical patients with cancer of the stomach? Scand $\mathcal{F}$ Gastroenterol 1987; 22 (suppl 133): 76-9.

11 Walls WJ. The evaluation of malignant gastric neoplasms by ultrasonic B-scanning. Radiology 1976; 118: 159-63.

12 Efsen F, Fishcherman K. Angiography and gastric tumours Acta Radiologica Diagnosis 1974; 15: 193-7.

13 Picus D, Balfe D, Koehler R, Roper C, Owen J. Computed tomography in the staging of esophageal carcinoma. Radiology 1983; 146: 433-8.

14 Lee KR, Levine E, Moffat RE, Bigongiari LR, Hemreck AS Computed tomographic staging of malignant gastric neoplasms. Radiology 1979; 133: 151-5. 
15 Balfe DM, Koehler RE, Karstaedt N, Stanley RJ, Sagel SS Computed tomography of gastric neoplasms. Radiology 1981; 140: 4312-6.

16 Moss AA, Schnyder P, Marks W, Margulis AR. Gastric adenocarcinoma: a comparison of the accuracy and economics of staging by computed tomography and surgery. Gastroenterology 1981; 80: 45-50.

17 Freeny PC, Marks WM. Adenocarcinoma of the gastro-

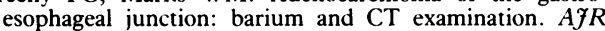
1982; 138: 1077-84.

18 Komaki S, Toyoshima S. CTs capability in detecting advanced gastric cancer. Gastrointest Radiol 1983; 8: 307-13.

19 Sussmann SK, Halvorsen RA, Illescas FF, Cohan RH, Saeed M, Silverman PM, et al. Gastric adenocarcinoma: CT versus surgical staging. Radiology 1988; 167: 335-9.

20 Grote R, Döhring W, Meyer HJ, Schmied W, Löhlein D. Computertomographie bei malignen Tumoren des Magens. Computertomographie bei malignen Tur
Fortschr Röntgenstr 1984; 141: 654-60.

21 Stöltzing H, Thon K, Pohl C, Mariß G, Röher HD. Stellenwert des Computertomogramms für das präoperative Staging beim Magenkarzinom. Z Gastroenterol 1989; 27: $601-5$

22 Dehn TCB, Reznek RH, Nockler IB, White FE. The preoperative assessment of advanced gastric cancer by computed tomography. Br F Surg 1984; 71: 413-7.

23 Grosser G, Wimmer B, Ruf G. Diagnostischer Wert der Computertomographie beim Magenkarzinom. Fortschr Röntgenstr 1985; 142: 514-9.

24 Ruf G, Kirste G, Grosser G, Wimmer B, Fiedler L. Stellenwert der Computertomographie in der Diagnostik des Magenkarzinoms aus chirurgischer Sich. Aktuel Chir des Magenkarzi.

25 Vallgren S, Hedenbro J, Götberg S, Walther B. Preoperative computed tomography for evaluation of tumor growth in patients with gastric cancer. Acta Chir Scand 1985; 151: $571-3$

26 Schröder R, Triller J, Roder R. Wert der Computertomo graphie beim fortgeschrittenen Magenkarzinom. Ist die Probelaparotomie vermeidbar? Schweiz Med Wochenschr 1986; 116: 956-7.

27 Cook AO, Levine BA, Sirinek KR, Gaskill HV. Evaluation of gastric adenocarcinoma. Abdominal computed tomography does not replace celiotomy. Arch Surg 1986; 121: 603-6.

28 Kleinhaus U, Militianu D. Computed tomography in the preoperative evaluation of gastric carcinoma. Gastrointest preoperative evaluation
Radiol 1988; 13: 97-101.

29 Mason RC, Rankin S, Taylor PR, Rowe PH, Linsell J, Owen $\mathrm{WJ}$, et al. Computerised tomographic scanning and staging of gastric carcinoma. Laniet 1987; i (letter): 108

30 Rhode H, Rau E, Gebbensleben B, Zuverlässigkeit der prä-, intra- und postopertiv- pathologischen Stadieneinteilung beim Magenkarzinom entsprechend den C-Kategorien. In
Rohde H, Troidl H, Hrsg. Das Magenkarzinom-Methodik klinischer Studien und therapeutischer Ansätze. Stuttgart: Thieme Verlag 1984; 106-17.

31 Tio TL, Coene PLO, Schouwink MH, Tytgat GNJ. Esophagogastric carcinoma: Preoperative TNM classification with endosonography. Radiology 1989; 173: 411-7.

32 Ziegler K, Sanft C, Zeitz M, Stein H, Häring R, Riecken EO Endosonography as a new clinical tool in staging gastric carcinoma [abstract]. Gastroenterology 1989; 95 (suppl): A111.

33 Ziegler K, Sanft C, Zeitz M, Riecken EO. Preoperative staging of gastrointestinal tumors by endosonography. Surg Endosc 1990; 4: 154-60.

34 Kennedy BJ. Evolution of the international gastric cancer staging classification. Scand F Gastroenterol 1987; 22 (suppl 133): 8-10.

35 American joint committee for cancer staging and end-results reporting. Manual for staging of cancer. Chicago: American joint committee, 1978; 75-6.

36 Rhode H, Rau E, Köster R, Gebbensleben B, Stützer H. A surgeons checklist for a standardized staging procedure in patients with cancer of the stomach. Scand $\mathcal{F}$ Gastroenterol 1987; 22 (suppl 133): 36-9.

37 Hermanek P, Sobin LH, eds. TNM-classification of malignan tumours. 4th ed. Berlin: Springer 1987; 29.

38 Kramer MS, Feinstein AR. Clinical biostatistics LIV. The biostatistics of concordance. Clin Pharmacol Ther 1981; 29. 111-23.

39 Landis RJ, Koch GG. The measurement of observer agreement for categorial data. Biometrics 1977; 33: 159-4.

40 Kramer MS. Clinical epidemiology and biostatistics. Berlin: Springer-Verlag 1988;201-16.

41 Odeh RE, Owen DB. Attribute sampling plans, tables of tests and confidence limits for proportions. Statistics, textbooks and monographs. New York: Marceel Dekker 1983; 85-145.

42 Hald A. Statistical tables and formulas. New York: John Wiley 1952; 66-9.

43 Madden MV, Price SK, Learmonth GM, Dent DM. Surgical staging of gastric carcinoma: sources and consequences of error. Br F Surg 1987; 74: 119-21.

44 Quint LE, Glazer GM, Orringer MB, Gross BH. Esophageal carcinoma: CT findings. Radiology 1985; 155: 171-5.

45 Thon K, Stöltzing H, Verreet P, Röher HD. Therapie- und prognoserelevante Stadieneinteilung beim Magenkarzinom prognoserelevante Stadieneint

46 Rhode H, Köster R, Gebbensleben B, Stützer H, Rau E. Errors of surgical staging in patients with cancer of the stomach. Scand $\mathcal{F}$ Gastroenterol 1987; 22: 27-30.

47 Ziegler K, Sanft C, Zeitz M, Felsenberg D, Stein H, Riecken $\mathrm{EO}$. Evaluation of endosonography in Tn staging of esophageal cancer. Gut 1991; 32: 16-20. 